\title{
Infrequent presentation of giant cell arteritis
}

\author{
Carmen García-Cabo, Lorena Benavente, Sergio Calleja
}

Department of Neurology, Hospital Universitario Central de Asturias, Oviedo, Spain

\section{Correspondence to}

Carmen García-Cabo,

c.garciacabo@gmail.com

Accepted 21 December 2015
CrossMark

To cite: García-Cabo C, Benavente L, Calleja S. BMJ Case Rep Published online: [please include Day Month Year] doi:10.1136/bcr-2015213973

\section{DESCRIPTION}

A 78-year-old man with a history of atrial fibrillation and hypertension was admitted to the hospital for a mild left hemispheric stroke. He reported having jaw claudication, frontotemporal headache and malaise for the past several months. MRI angiography of the brain revealed occlusion of both vertebral arteries and significant stenosis of the left supraclinoidal internal carotid artery (ICA) (figure 1A, C). The vessel wall of the aortic arch, and origin of the vertebral arteries and left ICA were enhanced after gadolinium injection (figure 1B), suggesting the presence of vasculitis, in this case giant cell arteritis (GCA) confirmed by temporal biopsy. The patient was treated with prednisone $1 \mathrm{mg} / \mathrm{kg}$ for 10 days and then a given descending dose, with consequent clinical status and ICA stenosis improvement (figure 1D).

GCA presenting as multiple large vessel stenosis is a rare and often underdiagnosed disease, ${ }^{1}$ and radiological findings of MRI may suggest the diagnosis. ${ }^{2}$ Despite treatment, vascular stenosis is rarely resolved. In case of early diagnosis and treatment, the involvement of large vessels in GCA can be partially resolved. ${ }^{3}$

\section{Learning points}

- Large vessel occlusion in giant cell arteritis is a rare manifestation of the disease.

- MRI angiography with gadolinium injection is a sensitive test to detect intramural vessel inflammation.

- The resolution of vascular stenosis after steroid treatment is rare, but can occur if treatment is started at an early stage.

\section{Competing interests None declared.}

Patient consent Obtained.

Provenance and peer review Not commissioned; externally peer reviewed.

\section{REFERENCES}

1 Cull RE. Internal carotid artery occlusion caused by giant cell arteritis. J Neurol Neurosurg Psychiatry 1979;42:1066-7.

2 Siemonsen S, Brekenfeld C, Holst B, et al. 3T MRI reveals extraand intracranial involvement in giant cell arteritis. Am J Neuroradiol 2015;36:91-7.

3 Ahdab R, Thabuy F, Menager de Froberville E, et al. Reversible vertebral artery stenosis following corticotherapy in giant cell arteritis. Eur Neurol 2008;59:331-3.

Figure 1 (A) Left internal carotid artery (ICA) stenosis and vertebral artery occlusion. (B) ICA wall enhanced after gadolinium injection. (C) Left ICA before steroid treatment. (D) Left ICA after steroid treatment.

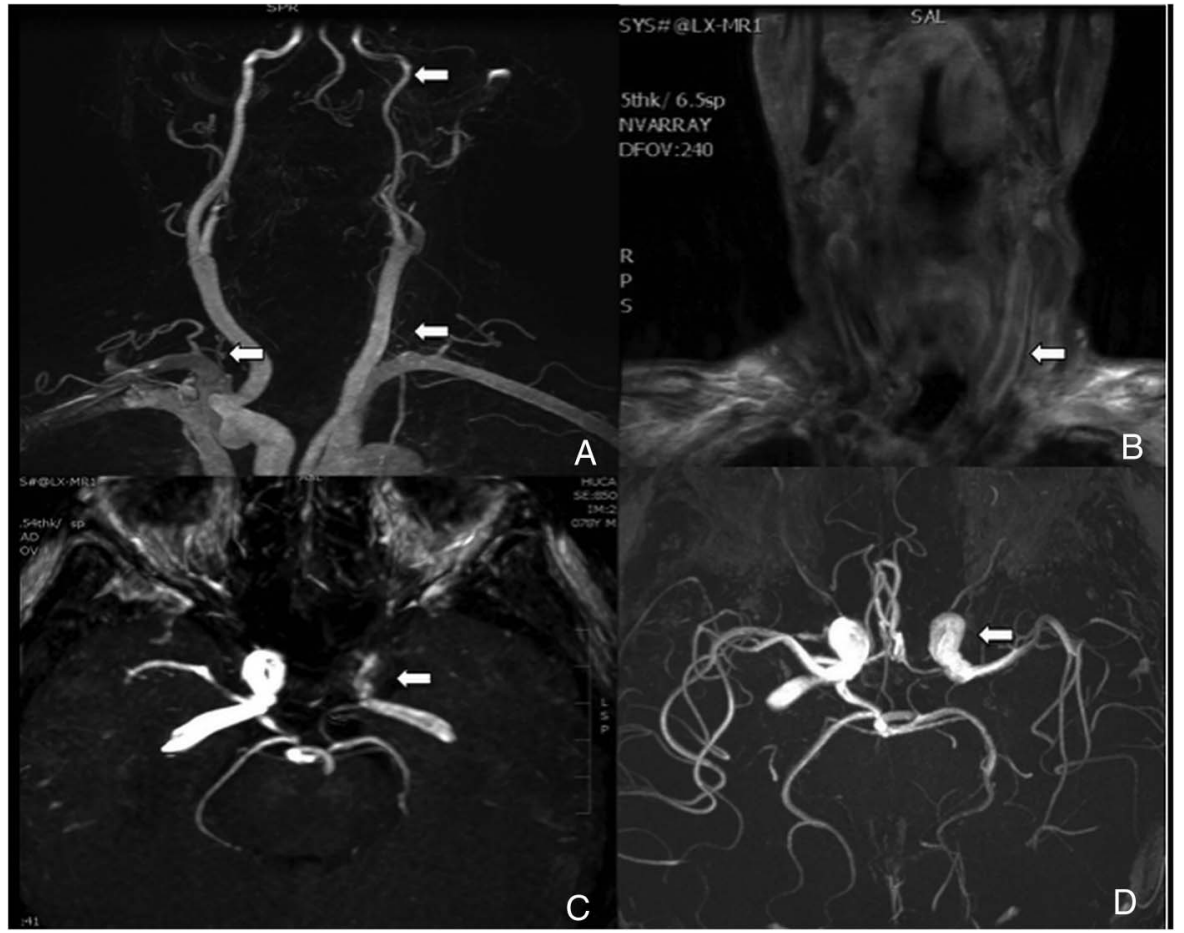


Copyright 2016 BMJ Publishing Group. All rights reserved. For permission to reuse any of this content visit http://group.bmj.com/group/rights-licensing/permissions.

BMJ Case Report Fellows may re-use this article for personal use and teaching without any further permission.

Become a Fellow of BMJ Case Reports today and you can:

- Submit as many cases as you like

- Enjoy fast sympathetic peer review and rapid publication of accepted articles

- Access all the published articles

- Re-use any of the published material for personal use and teaching without further permission

For information on Institutional Fellowships contact consortiasales@bmjgroup.com

Visit casereports.bmj.com for more articles like this and to become a Fellow 